\title{
nature
}

\author{
26 March 1981
}

\section{Reagan's non-existent science advisors}

Why is the Reagan Administration dragging its feet on the appointment of a Science Advisor in the White House? More than two months have now passed since Dr Frank Press packed his bags and left. From time to time, this or that distinguished person has been mentioned as a possible successor, only to sink beneath the waves of gossip again. The President's budget request dutifully includes provision for a Science Advisor and a small staff, but at the present rate the new fiscal year will have begun before the Administration will be writing cheques against this line item. It is, however, inconceivable that the motive for the delay in appointing a successor to Dr Press is simply parsimony. Even the new stringent budget includes many more extravagances than this modest office. Nor is it likely that the failure to appoint a Science Advisor stems from a lack of qualified candidates. Although some of those mentioned in connection with this office are probably too accustomed to speaking out in public to suit the White House, there can be no enduring shortage of people able to take on the job. Moreover, it is unlikely that President Reagan's White House is fearful that anyone appointed to the post would have to walk in Dr Press's shadow for too long. By common consent, Dr Press did the job superbly, but the new Administration seems not to have been shy of appointing less well known people to other posts previously occupied by relative giants.

The most charitable explanation is that the new Administration has sought to avoid the encumbrance of a Science Advisor while putting together its budget request. And it is easy enough to understand what a nuisance such a person would have been in the past few weeks. The proposal to cancel the United States half of the joint mission, with the European Space Agency, to put a pair of satellites in polar orbits about the Sun would have evoked a string of memoranda explaining that such a course of action might permanently damage the chances of international collaboration on technical projects. Similarly, the Administration may have calculated, the plan to take the National Science Foundation out of science education would certainly have produced a reflex reaction from any Science Advisor anxious to keep his links intact with former colleagues in the wider world. More memoranda would have filtered over from the Old Executive Office. President Reagan's spirits must have sunk quite low at the prospect that a newly appointed Science Advisor, anxious to make his mark alongside the Killians and Wiesners, would have chosen to offer unsolicited and largely unusable (let alone unwelcome) advice about the new Administration's armoury and its lack of policy (so far) on arms control. Why not wait until the summer, when some of the dust will have settled, before inviting such unnecessary problems? On this charitable calculation, the next President's Science Advisor will be tapped on the shoulder some time about midsummer, when his or her plans to spend a vacation at Woods Hole, Aspen or in Europe are too far advanced to be cancelled easily, will take up of fice in the middle of the next frenzied budget process, and will not start writing awkward memoranda until fiscal 1983 dominates everybody's thoughts. That is the charitable calculation of the new Administration's most charitable motivation.

Unfortunately, more sombre, even sinister calculations are possible. Is there, for example, a chance that the Administration has it in mind never to appoint a successor to Dr Press, not because it seeks to make a modest saving in the budget but because, as a matter of principle, it has decided that it does not want to be encumbered with such a person? Purists will quickly say that no modern administration would harbour such a thought. Has it not been amply demonstrated, ever since the end of the Second World War, that every administration needs a Science Advisor? Did not President Nixon's abolition of the President's Science Advisory Committee (not yet restored, even though Congress would like it back) show what harm can come to those who stab the research establishment in the back? One day, the calculation goes, there will be a constitutional amendment making the office of Science Advisor a part of the machinery of government, and from then on there will be no hesitation. Unfortunately, this simple calculation is wrong. It is probable that President Reagan has persuaded himself that if he cannot find a Science Advisor with all the virtues (distinction, discretion and an unwillingness to write memoranda unless asked), he will do without one. In that, he will be mistaken.

The case for having some kind of Science Advisor is subtle, administrative rather than an issue of principle. It is fashionable to say that science is so important that any president must have his own captive source, but that too stems from a mistaken view of what the world is like. The White House is not short of technical advice. Every government agency in Washington can supply a stream of memoranda to match whatever Dr Press's putative successor writes. The particular function of a Science Advisor in the White House is to hold the ring between the several warring agencies of government that ask contradictory (and impossible) tasks of every government - make unemployment go away, preferably by the encouragement of small business; make universities the powerhouses of innovation but less of a charge on the public purse; ensure peace by some technical device, but provide that if there is trouble in Central Europe, the United States will not be on the losing side. (A Science Advisor worth his salt will also be ready with opinions on whether the MX missile should be based in Utah or at sea, but may not again be required to advise, as in President Kennedy's time, on the best way to grow cranberries in Massachussetts.) In the last resort, however, what matters about the function of the Science Advisor in the White House is not the content nor even the quality of the advice rendered, but the fact of his or her existence. He or she is a lightning-rod, able to concentrate and then harmlessly to discharge the discontents of a powerful constituency. The constituency is not, however, all that powerful, these days, but short of funds and also of friends. An Administration with its wits about it would appoint a Science Advisor now, while it can still choose. If Mr Reagan delays much longer, he will find that he has less choice.

\section{How not to run telecommunications}

The British government seems well on the way to making a hash of its policy on telecommunications. Almost since last July, when the Secretary of State for Industry, Sir Keith Joseph, first spelled out the terms on which the old Post office monopoly would be relaxed, the House of Commons has been struggling with a nasty compromise of a bill for the reorganization of the British Post Office. The proposal to separate the businesses of handling the mails and of managing telecommunications is sensible, if long 